\title{
Refahın Yeniden Dağıtımı: Türkiye'de Makroekonomik Yapı Buna İmkân Sağlıyor Mu?
}

\author{
Redistribution of Welfare: Does Macroeconomic Framework Make It Possible?
}

\author{
Mehmet Çanakçı*(iD
}

Department of Public Finance, Inonu University, Malatya, Turkey

\begin{abstract}
Received: 25.12 .2020
Accepted: 02.04.2021

This article was checked by intihal.net

Öz

Refah devletinin amacı, yurttaşlarına kaliteli ve uygun bir refah düzeyini karşılamak ve vatandaşların olumsuzluklar karşısında yaşam şartlarının kötüleşmesini önlemektir. Gelişmiş toplumlarda genellikle sosyal devlet olmanın en temel göstergesi olarak ülkede yaşayan her bireyin kendini güven içerisinde hissetmesi ve kendini özgürce ifade edebilmesi önemli eşiktir. Bu bağlamda ekonomik büyüme ve kalkınmanın sağlanması amacıyla piyasa başarısılıklarını ortadan kaldırmak, gelir dağılımında adaleti tesis etmek, sosyal güvenliğin daraltıcı olmadan tabana yayılmacı bir modelle kurgulamak, sermaye yatırımlarını teşvik etmek, ekonomik faaliyetlerin ideal koşullar içerisinde yani potansiyel olarak en yüksek seviyede istihdam seviyesini yakalayarak ekonomik döngüyü oluşturmak refah devletinin bir bütünsel olarak uygulamalarıdır. Bir refah devleti programı olarak, Evrensel Temel Gelir uygulamasının klasik refah devleti programlarından ayrıldığı nokta, klasik refah programlarının gelir eşitliğini önceleyen, mağduriyet giderici nitelikte olmasıdır. Oysaki Evrensel Temel Gelir (Universal Basic Income), fırsat eşitliğini önceleyen, mağduriyet önleyici nitelikte bir programdır. Bu iktisat yazında refahın yeniden dağııımının günümüz makroekonomik sistemde bireye güvence sağlanmasının çeşitli kavramsal ve kuramsal çerçevesi üzerinden yeniden düşünmemiz gerektiğini, finansal araçların daha etkin kullanımıyla sürdürülebilir büyümenin refaha etki edebileceğini göstermektedir.
\end{abstract}

Anahtar Kelimeler: Refah Devleti, Evrensel Temel Gelir, Makroekonomi, Ekonomik büyüme ve kalkınma

\section{Abstract}

The aim of the welfare state is to provide its citizens with a quality and appropriate level of welfare and to prevent the deterioration of the living conditions of the citizens in the face of the negative. In developed societies, the most basic indicator of being a social state is that every individual living in the country feels safe and express himself freely. In this context, in order to ensure economic growth and development, to eliminate market failures, to establish justice in income distribution, to ensure that social security is structured with a broad-based model without constricting, encouraging capital investments, conducting economic activities in ideal conditions and at full employment level is a holistic of the welfare state. as applications. As a welfare state program, the point where Universal Basic Income practice differs from classical welfare state programs is that classical welfare programs prioritize income equality and are grievous. However, Universal Basic Income (Universal Basic Income) is a program that prioritizes equality of opportunity and has an unjust treatment. This economics literature shows that the redistribution of welfare and the assurance of the individual in today's macroeconomics system must be rethinked through various concepts and theories.

Keywords: Welfare State, Universal Basic Income, Macroeconomics, Economic Growth and Development.

Çanakçı, M. (2021). “Refahın Yeniden Dağıtımı: Türkiye'de Makroekonomik Yapı Buna İmkân Sağlıyor Mu?”, Journal of Academic Value Studies 7(1) (2021) 15-30 (http://dx.doi.org/10.29228/javs.48554).

\footnotetext{
*E-mail address: mehmet.canakci@inonu.edu.tr
} 


\section{Giriş}

Refah devleti, kendisini liberal demokratik toplumların tanımlayıcı kurumlarından biri olarak kurmuştur. Sosyal bilimlerde refah devleti, çeşitli ideolojik ve politik iknaların teorisyenlerini ve analistlerini cezbetmiştir. Refah devleti çalışmalarının cazibesi, yalnızca sosyal politikanın geniş doğasında değil (gelişmiş kapitalist toplumlarda devlet faaliyetlerinin neredeyse dörtte üçünü kapsar), aynı zamanda insan refahını teşvik edecek şekilde yaşam koşullarını değiştirmedeki rolünde yatmaktadır. Refah devleti, ekonomik istikrarın var olduğu, toplum içerisinde gelir dağıımının, güç dağılımının ve hizmet dağııııının hukukun üstünlüğüyle daima oluştuğu ve üretim-tüketim zincirinin sürdürülebilir ekonomik değer yarattığı kapitalist bir ekonomide piyasa güçlerini değiştirmek için tasarlanmış bir dizi politik, sosyal ve ekonomik müdahaleyi ifade eder. Asa Briggs, refah devletini "örgütlü gücün (siyaset ve idare yoluyla) kasıtlı olarak piyasa güçlerinin karşılıklı etkileşimini değiştirme çabasıyla kullanıldığı" bir devlet olarak nitelendiriyor. Bu nedenle, refah devletinin genel amacı, insan refahının artııımasına yardımcı olan yaşam koşullarını yaratmak ve sürdürmektir. (Karimi, 2017).

Refah Devleti Kavramı, her ne kadar antik dönemlerden bu yana entelektüel düzlemde tartışıla gelen bir mesele olsa da, köklerini 1929 Büyük Buhranındaki yıkım, ardından gelen II. Dünya Savaşı ve SSCB dominyonunda Doğu Avrupa'da birçok sosyalist cumhuriyet çıkmasından sonra, günümüzde 'Gelişmiş Ülke' kategorisine soktuğumuz Batı Avrupa ve Kuzey Amerika ülkelerinde uygulanmaya konulmuştur. (Reeskens, 2020).

ABD'de New Deal (negatif olarak), İskandinav Ülkeleri'nde üçüncü yol (pozitif olarak) örnek gösterilen en yaygın Refah Programlarıdır. Aynı zamanda, yine bir üçüncü yol politikası olan ve Almanya'da uygulanan Ordoliberalizm de Almanya'yı II. Dünya Savaşı'nın yıkımından çıkartan bir formül olarak önümüze çıkmaktadır.

Refah Devleti Programları, genel olarak büyük bürokrasi ve yüksek vergilendirme yoluyla gelirin yeniden dağıtılması ve vatandaşlara bir çeşit güvenlik önlemi olarak sunulması şeklinde gerçekleşmektedir. Refah Devleti Programlarının en büyük iki ayağı, emeklilik ve sağlık hizmetlerinin sosyalizasyonudur.

Gelişmekte olan dünyada içinde bulunduğumuz yıllarda COVID-19 salgın hastalığının vaka oranı yükseldikçe, iş kayıplarının ve gelirin tersine dönmelerinin potansiyel olarak yıkıcı maliyetlerini ortaya çıkaracağı tabloyla karşı karşıyayız. Koşulsuz acil nakit transferleri, COVID-19 krizinin hâlihazırda sosyal yardım veya sigorta korumasına erişimi olmayan yoksul ve yoksulluğa yakın haneler üzerindeki en kötü anlık etkilerini azaltabileceği düşünülerek, ülkelerdeki insanlar için, yoksulluk sınırının üzerinde minimum garantili bir gelir ödemeleri yapılmaktadır (Molina vd.2020). Ancak hedeflenen uygulamanın, küresel salgınlarla yâda krizlerle karşılaşılmadan insan onuruna yakışacak, ekonomik kalkınma amaçı temel insani ihtiyaçları bireylerin hizmetine sunmak gerekmektedir. Bu gibi krizlerden sonra ekonomiyi yeniden dengelemek ve yeniden canlandırmak için orta ve uzun vadeli planlamaya ihtiyaç vardır. Güçlü ve sürdürülebilir iş modellerine sahip olan ülkelerin gelişmeye devam edebilmesi için ilgili sektörlere göre, sektör planlarını ve sosyal güvenlik yapılarını güçlendirme temelli teşvik edici ekosistemi içeren geniş bir sosyoekonomik kalkınma planına ihtiyaç vardır (Nicola, vd. 2020). Hükümetlerin ve finans kurumlarının kendi stratejik pozisyonları sürekli olarak yeniden değerlendirmeleri "ne olursa olsun" sözünün gerçekten olumsuz koşulların varlığında bile yerine getirilmesini sağlaması intiyatı bir davranıştır. Aksi takdirde sadece dönemlik/geçici gelir araçlarına başvurarak krizlerin etkilerini azaltıcı yöntemlere başvurmak başta sosyal güvenlik sisteminin derinleşmesini engeller, sosyal harcamaların faydasını azaltır, toplumsal ekonomik yapının döngüsü adil olarak bölüştürülemez, bu şekilde yapılacak geçici her bir finansman ödemesi gelişmekte olan ülkelerin kalkınma sorununu daha da derinleştirmektedir. (Saha ve Mishra, 2020).

Makale, beş ana başlık üzerine inşa edilecektir. Çalışmada öncelikle Refahın yeniden dağııımı ve sosyal adalet kavramları üzerinde durulacak, ardından sosyal refah fonksiyonları kapsamında yer alan Thomas Paine 'in 'Tarımsal Adalet' kavramı ve John Rawls'ın 'Bir Adalet Teorisi' eserleri temel alınarak, refah devletinin etik tarafı incelenecektir. Sonrasında günümüz refah devletlerinin bürokraside ve kamu bütçesinde yarattığı yıkım ve bunun çözümü olarak görece modern fakat kökleri çok eskilere giden 'Evrensel Temel Gelir' kavramı sosyal adaletin sağlanabilmesi açısından incelenecektir. Sonuç olarak, refah devletinin gençler ve aile başta olmak üzere toplumun her kesimine yoğunlaşması gerekliliği üzerinde Makroekonomik perspektifle durulacaktır. Ayrıca son bölümde, refahın yeniden dağıtımına yönelik günümüz küresel konjonktüründe politika önerileri sunulacaktır. 


\section{Refahın Yeniden Dağıtılması ve Sosyal Adalet İlişkisi}

Çalışmanın bu kısmında öncelikle Refah iktisadının temelleri hakkında bilgi verilecek ardından refah iktisadını sağlamaya yönelik temel teoremlerden bahsedilecektir. Ayrıca Sosyal Adalet kavram olarak açıklanacak, sosyal adaletin sağlanmasına yönelik kriterler açıklanarak Türkiye'de sosyal adaleti sağlama ve Refahın yeniden dağııımına yönelik Anayasa'da ve diğer mevzuatlarda yer alan hükümlere de kısaca değinilecektir.

\subsection{Refah İktisadının Temel Problemleri}

iktisadın tanımında kıt olan kaynaklarla sınırsız ihtiyaçların karşılanması şeklinde bir söz gelenek haline gelmişse de bu ifadenin yerine mevcut kaynaklar ile en fazla çıktı ve faydanın elde edilerek kaynakların yerli yerinde harcanması açıklaması daha doğru olacaktır. Tam rekabet koşulları içerisinde pareto optimalite kendiliğinden sağlanmış olacağı için devletin kaynakları yeniden dağıtma gibi bir problemi olmayacaktır. Bununla birlikte mevcut kaynak dağılımı ve nispi fiyat yapısı bozulmadan devletin vergiler ve kamu harcamaları vasıtasıyla bireyler arasında transfer yapması da pareto optimalite açısından uygun olacaktır. Pareto optimalite şartlarının tüm sektörlerde sağlandığı durum birinci en iyi teori olarak adlandırılır. Bu noktada $\mathrm{P}=\mathrm{MC}$ koşulu sağlandığı için fiyatlarda herhangi bir sapma olmaksızın ekonomide etkinliğin sağlanıldığı söylenebilir. Eğer ekonomide MC=P koşulu piyasalarda gerçekleşmiyor ise devletin yeniden tüm sektörlerde etkinliği sağlayabilmek adına ekonomiye müdahalede bulunması ve refahı yeniden sağlaması gerekir(Öğretir,2020:45).

\subsection{Sosyal Refahın Sağlanmasına(Refahın Yeniden Dağıtımı) Yönelik Görüşler}

Sosyal refahın ne olduğunu açıklamada teorisyenler sosyal refah fonksiyonlarından hareket etmiştir. Sosyal refah fonksiyonu ise bireylerin refahlarından toplam refaha ulaşabilmek için bir bağ kurulması esasına dayanan bir fonksiyondur. Pareto optimalitenin sağlanabileceği alternatif sosyal refah tercihlerinden oluşan bu fonksiyonu BergsonSamuelson geliştirmişlerdir (Sen, 1973:7).

Sosyal refahın sağlanabilmesi adına birçok görüş bulunsa da bunlar arasında bilimsel çalışmalarda daha fazla yer edinmiş temel üç tane görüş vardır: Bentham(Faydacı) sosyal refah fonksiyonu, Bergson-Samuelson refah fonksiyonu ve Rawlsçı sosyal refah fonksiyonudur.

\subsubsection{Benthamcı (Faydacı) Sosyal Refah Fonksiyonu}

Benthamcı sosyal refah fonksiyonuna göre toplumun toplam refahı bireylerin refahlarının toplamından oluşmaktadır. Eğer toplumsal refahın artırıması isteniyorsa bireylerin refahını artırmaya yönelik politikalara ağılık vermek gerekir. Eğer toplumda bazı bireylerin refahı azalmasına rağmen diğer başka bireylerin refahı artıyor ve sonuçta toplam refah artıyorsa devletin bu şekilde refahı yeniden dağıtması faydacı yaklaşıma göre istenilebilen bir durumdur (Sen, 1973:16).

\subsubsection{Bergson-Samuelson Sosyal Refah Fonksiyonu}

Bergson- Samuelson sosyal refah fonksiyonuna göre bireylerin tercih sıralaması takip edilerek sosyal refaha ulaşabilmek mümkündür. Bu refah yaklaşımına göre bireylerin refahı ölçülemez fakat sıralanabilir. Bireyler yaptıkları tercih ler neticesinde elde ettikleri faydaları en çoktan en aza doğru sıralayabilirler. Bu yaklaşıma göre sosyal refah birinci bireyin faydası ile ikinci bireyin faydası arasında kayıtsız kalınan noktada gerçekleşir (Albayrak, 2003:56-57).

\subsubsection{Rawlsçı Sosyal Refah Fonksiyonu}

1921 yılında orta-alt sınıf bir ailede doğan John Rawls'ın çocukluğu ve gençliği Büyük Buhran ve İkinci Dünya Savaşı'nın yıkımı içinde geçti. Abisinin tedavi edilebilir bir hastalıktan dolayı ölmesi, John Rawıs'ın karakterini ve akademik hayatını oldukça derin bir biçimde etkilemiştir.

John Rawls, 'Bir Adalet Teorisi' isimli eseriyle özellikle Bill Clinton ve Amerikan Liberallerini düşünsel olarak etkilemiş bir düşünürdür. Hatta Bill Clinton'un değimiyle John Rawls; 20. Yüzyılın en etkili siyaset felsefecisidir.

John Rawls'ın teorisi aslında oldukça basittir. Dünyaya gelmeden önce tamamen bilgisiz bir durumda, tercih özgürlüğümüz olmayan bir biçimde adeta asılı durmaktayızdır. Ünlü bir cerrahın tek çocuğu olarak da, fakir ve zenci bir annenin yetim çocuğu olarak da doğma şansımız vardır. Rawls bu durumu bir lotoya benzetir. Her türlü kimlikten sıyırılmış, tanrısal bir varlık olarak adalet sistemini dizayn etme deneyini ise 'Cehalet Perdesi' tabiri ile açıklamaya çalışır. Her bireyin, azim ve çalışkanlık yoluyla istediği ideal hayata erişmesi fikrine katılmakla beraber, şu soruyu sorar; Ya çevresel faktörler, ideal hayata erişmemiz noktasında bir engel oluşturuyorsa? 
Ya eğitimsiz bir ailede doğmuşsak ve çocukken ailemizden baskı görmüşsek? Ya yeterli sağlık hizmetlerine kavuşamadığımız için basit hastalıklardan dolayı ölürsek? Ya ten rengimizden ötürü sistemin yarattığı imkânlara erişimimiz kısıtlanmak suretiyle adaletsizliğe maruz kalırsak? Elimizde olmayan durumlardan ötürü sistem dışına itilmek gerçekten adaletli midir?

John Ralws'ın 'Bir Adalet Teorisi' isimli eseri, hem etik açıdan, hem de metodolojik açıdan refahın yeniden dağııımını temiz, net ve tartışmasız bir biçimde açıklama iddiasındadır. Etik açıdan, refahın yeniden dağııımı tanrısal bir bakış açısından herkesin fırsat eşitliğini temin edecek şekilde düzenlenmeli, metodolojik açıdan ise, herkesin eşit şartlarda sorgusuz, sualsiz, bürokrasisiz yarışa başlama imkânı garanti altına alınmalıdır.

Ancak bu noktadan sonra bireylerin azimleri ve çalışkanlıkları bir fark yaratabilir. John Rawls’a göre refahın yeniden dağıtımı, fırsat eşitliğini garanti etmesi açısından dört sacayağına sahiptir; (Rawls, 1971)

1) Bireyler, medeni bir insan olmaları sonucunu getirecek, eşit ve kapsayıcı bir eğitim imkânına kavuşmalıdır.

2) Bireyler, beklenmedik sakatlıklara karşı güvence altında olmalıdır.

3) Bireyler, hiçbir faktöre bakılmaksızın, hukuksal olarak eşit statüde olmalıdır.

4) Bireyler, çocukluklarından itibaren nezih bir semtte, nezih bir evde yaşamalıdır.

Günümüz refah devletleri, iki noktada John Rawls 'un cehalet perdesine takılmaktadır. Birincisi; günümüz refah programları, bireyleri doğdukları andan itibaren fırsat bakımından iyileştirme amacı taşımamakta, aksine fırsat eşitliği olmayan bireyler sefil duruma düştükten sonra devreye girmektedirler. İkincisi; refah devletleri fırsat eşitliğini sağlamaktan ziyade, çıktıları eşitleme çabası gütmekte, bu da bireyin azmini ve çalışkanlığını baltalamaktadır.

John Rawls'a göre refah devletleri, doğuştan gelen dezavantajları sıfırlama amacı güttüğü müddetçe etiktir, sefil duruma düştükten sonra bürokrasiye yardım formları doldurmak yoluyla bireyleri dilenciliğe düşürmek etik olan nokta değildir.

\subsubsection{Sosyal Refahın Sağlanmasında Tarımsal Adalet}

Amerikan Bağımsızlık Savaşı́nın ve yeni kurulan federal yapının fikri altyapısının öncülerinden birisi olan Thomas Paine, 'Agrarian Justice (Tarımsal Adalet)' isimli bir makale ile gelir eşitsizliğinin tanımlanmasında bir dönüm taşı oluşturmuştur.

Thomas Paine, bu makalesinde temel olarak, kamuya (kraliyet ailesine) ait arazilerin özelleştirilmesini ve büyük tarım arazilerinin sahiplerine \%10 oranında uygulanacak bir vergi ile bir emeklilik sistemi ve vatandaşlık maaşı ödemesi yapılmasını önermiştir. Ortalama yıllık maaşın 23 Sterlin olduğu dönemin Birleşik Krallığı'nda, 50 yaş üzeri emeklilere senelik 10 Sterlinlik ve 21 yaş üzeri her erkek ve kadına senelik 15 Sterlinlik bir ücret verilmesini savunmuş, toplanan vergilerin kalan kısmının ise 'sakat ve körlere' engelli maaşı olarak bağışlanmasını savunmuştur.

Thomas Paine 'in vatandaşlık maaşını andıran görüşleri Malthus ve David Ricardo tarafından eleştiriye tutulmuştur. Malthus, bu tarz bir yeniden dağıtım politikasının nüfusu aşırı artıracağı ve kıtıkların baş göstereceği şeklinde okumuş ve eleştirisini sunmuşken, David Ricardo, günümüzde de tartışıldığı biçimiyle insanlara karşııısız para vermenin tembelliği artıracağı ve buna bağı ılarak refah üretimini baltalayacağı yönünü ön plana koymuştur.

Teorinin uygulaması ve gelen eleştirilerden ziyade, Thomas Paine 'in bu makalesi, fakirlik tartışmaları konusunda bir eşik olmasından ötürü önemlidir. Çünkü fakirlik, tarih boyunca ilk defa kaçınılmaz bir durum veya tamamen ortadan kaldırılması gereken bir ayıp olarak değil, aksine Özgürlük ve Eşitlik dikotomisi üzerine ele alınmıştır. Ve fakirliğin çözümü olarak, o dönem sıkça dile getirilen sosyalist önlemler ( örneğin: Gracchus Babeuf'un aksiyona geçirmeye çalıştığı görüşler ) değil, negatif özgürlük ve pozitif özgürlük arasında bir üçüncü yol sunarak öne çıkmıştır. Thomas Paine, ne negatif özgürlükleri dışlamış, ne de pozitif özgürlükleri politik bir amaç olarak ele almıştır. Thomas Paine 'in Sosyal Adalet teorisinin izlerini ünlü Siyaset Felsefecisi John Rawls 'un Bir Adalet Teorisi isimli eserinde ve metodolojik farklılkları bir kenara bırakarak, etik bakımdan ABD Demokratik Partisi'nin Liberal kanadında açıkça görebilmekteyiz.

Thomas Paine 'in Tarımsal Adalet kavramının çıkış noktası aslında oldukça basittir. Toprak, doğası gereği işlenmemiş bir halde, insanlığın ortak malıdır. Fakat şartların mülk sahipliğini ve piyasayı getirdiği durumda, toprağın kamuya karşı bir kira bedeli karşılığında özelleştirilmesi ahlaken doğru olan noktadır (Paine, 1995).

Thomas Paine temelde, refah ödemelerine topluma ödenen kira olarak bakar ve argümanını bu şekilde temellendirir. Günümüz refah devletlerinin ahlaki duruşu ise, bireylerin hasbelkader var oldukları için toplumun düşeni 
vergilerle finanse edilen kamu kuruluşları yoluyla yeniden ayağa kaldırması şeklindedir. Peki, vergi nedir? Vergi, Halil Nadaroğlu'na göre; Bir devletin en temel asli unsuru olan vatandaşına hizmet etme zorunluluğunu, gerçekleştireceği her türlü kamusal etkinliklerinin kaynağını oluşturmak yâda karşılamak veyahut kamusal görevlerinin gereklerini yerine getirmek amacıyla ekonomik birimlerden yasada belirlenen çerçevelerde sınırlı kalmak üzere esas ve usuller içerisinde hukuki yaptırım altında, hususen bir menfaati belirtmeksizin geri ödememek suretiyle tahsil ettiği paralardır.(Nadaroğlu, 1998). Bu tanıma göre, vergilendirmenin hırsızlık veya müsadereden farkı, herkesin yararlandığı kamusal görevlerin yerine getirilmesidir. Soru, herkesin (aktif olarak) yararlandığı güvenlik, hukuk ve altyapı hizmetleri dışında kullanılmak üzere toplanılan vergilerin ahlakiliğini modern devletin etik temeli karşılayabiliyor mu? Açıkçası karşılamadığı yönünde görüşler hâkim. İnsanlar, kamusal ilişkilere ancak bir çıkar gözeterek girerler ve toplumu evlerinin, yani mülkiyet alanlarının, dışında tutarlar. Aslında her aile bir mikro devlet gibi çalışır ve o ailede toplumun fiziki olarak yeri yoktur. Herhangi bir karşılıklılık olmadan, bireyleri özel hayatlarına ortak etmediği topluma karşı sorumlu kılmak ve bu sorumluluğunu cebren karşılatmak pek de ahlaki bir nokta sayılmamalıdır.

Thomas Paine 'in bu eseri, refahın yeniden dağııımı konusunda vergilendirmenin ahlaki temelini (karşılıkılık) oluşturmak noktasında, refahın yeniden dağııımı için kullanılacak kaynakların sınııının belirlenmesi konusunda ve toplanılan kiranın nasıl dağıtılacağının sınırlarını belirleyerek, bürokrasiye sadece vergi toplama yetkisini vermek noktasında modern devletlere hala fikir verebilecek bir konumdadır.

\subsection{Sosyal Adaletin Tanımı ve Kapsamı}

Sosyal adalet kavramı normal adalet kavramından bazı hususlarda farklılık göstermektedir. Normal adalet genellikle bireylerin arasındaki ilişkiler için sağlanması gereken bir durum iken sosyal adalet toplum içerisinde bireyin bulunduğu konum açısından adaletin sağlanabilmesidir. Bu anlamda bireyin toplum içerisinde negatif ayrımcılığa maruz kalmaması, dışlanmaması ve bireye fırsat eşitliği sağlanarak ortaya çıkması muhtemel gelir farklılıklarının devlet tarafından azaltılmasıdır (Arslan,2020:149).

Ayrıca sosyal adaletin sağlanmasında dengeli bir gelir dağıımına ulaşabilmek için devletin sunduğu sosyal hizmetlerden ihtiyaç sahibi bireylerin mümkün olduğunca yararlanmasının sağlanması gereklidir Sosyal hizmetlerin niteliği ve miktarı çok önemlidir. Çünkü ancak yeterli düzeyde ve kaliteli sosyal hizmet sunumunun gerçekleştirilmesi ile fırsat eşitliğine ulaşmada katkı sağlanabilir (Kaynak,2017:256-257).

\subsubsection{Sosyal Adaletin Sağlanmasında Kriterler}

Bir toplum içinde sosyal adaletin yeterli düzeyde sağlanabilmesi için gerekli olan bir takım koşullar yer almaktadır. Bu koşulları kısaca belirtmek gerekirse refah ülkelerinde sosyal adaletin sağlanmasında aşağıdaki diğer kriterler de dikkate alınır:

$\checkmark$ Yoksulluğun azaltılması

$\checkmark$ iş̧ gücü piyasasına katıımın artması

$\checkmark$ Engelli ve bakıma muhtaç kişilere yönelik Sosyal güvenlik ve sosyal yardımların artıııması

$\checkmark$ Adil bir vergi düzeninin varlı̆̆

$\checkmark$ Eğitimde Fırsat Eşitliği(Kaynak,2017:257).

Çalışmanın bu kısmında önce sosyal adaleti sağlamada kullanılan kriterler kısaca açıklanacak ardından Türkiye'de bu kriterlerin ne ölçüde sağlanmaya çalışıldığına dair özet bilgiler içeren Tablolar yardımı ile verilecektir. Bu bölümün sonunda ise Türkiye'de sosyal adaleti sağlamada yararlanılan ilkelerin uygulanması konusunda genel olarak bir değerlendirme yapılacaktır.

\section{$\checkmark$ Yoksulluğun azaltılması}

Bireylerin bir başkasına muhtaç olmadan ihtiyaçlarını karşılayabilmeleri ve rahat bir yaşam sürdürme istekleri bütün dünyada ülkelerin ortak problemlerinden birisini oluşturur. Geçinebilecek geliri çok az olan ya da hiçbir gelire sahip olmadığı için yaşamlarını sürdürebilmeleri için bir başkasına bağlı olan kişiler yoksul olarak tanımlanmaktadır (Arpacıoğlu ve Yıldırım, 2011:61). 
Genellikle az gelişmiş ülkelerde daha sık görülen bir sorun olsa da gelişmekte olan ülkeler de yoksulluğun azaltılmasına yönelik kaynaklar ayırmaktadır. Devletler sosyal adaleti sağlayabilmek için mevcut kaynaklar ile el verdiği ölçüde yoksul birey sayısını azaltmayı sağlamak zorundadır. Bu durumun sağlanabilmesi için Ülkelerin milli gelir pastasından dar gelirli yoksul bireylerin azami ölçüde pay almalarını sağlamaya yönelik uygulamaları hayata geçirmesi gerekir (Çalışkan,2010:94).

Aşağıda Tablo 1'de seçilmiş bazı OECD ülkelerine ait 2015 yılını kapsayan yoksulluk oranları gösterilmektedir. Bu oranlar yoksulluk endeksine göre hesaplanmıştır. 2015 yılı gözlemlendiğinde seçilen ülkeler arasında yoksulluk oranı düzeyinin en fazla olan ülke olarak 0,172 değer ile Türkiye olduğu görülmektedir. Yine 2015 yılı incelendiğinde yoksulluk oranı 0,055 ile en düşük olan ülke Danimarka olarak görülmektedir. Bu durumun sosyal adaletin sağlanması açısından geliştirilmesi gereken bir konu olduğunu göstermektedir. Türkiye'nin bu konuda gelişme göstermeye ihtiyacı vardır.

Tablo 1. Seçilmiş OECD Ülkelerinde Yoksulluk Oranları, 2015

$\begin{array}{lc}\text { Ülkeler } & \begin{array}{r}\text { Yoksulluk } \\ \text { Orvanları(2015) }\end{array} \\ \text { Belçika } & 0,087 \\ \text { İsviçre } & 0,098 \\ \text { Çekya } & 0,091 \\ \text { Danimarka } & 0,064 \\ \text { İspanya } & 0,055 \\ \text { Estonya } & 0,153 \\ \text { Finlandiya } & 0,160 \\ \text { Fransa } & 0,063 \\ \text { Yunanistan } & 0,081 \\ \text { Macaristan } & 0,149 \\ \text { İtalya } & 0,085 \\ \text { Litvanya } & 0,144 \\ \text { Lüksemburg } & 0,165 \\ \text { Letonya } & 0,109 \\ \text { Hollanda } & 0,162 \\ \text { Norveç } & 0,078 \\ \text { Polonya } & 0,081 \\ \text { Portekiz } & 0,111 \\ \text { Slovenya } & 0,125 \\ \text { İsveç } & 0,092 \\ \text { Türkiye } & 0,092 \\ \text { Kaynak:OECD(2020), Poverty rate(indicator). }\end{array}$

\section{$\checkmark$ İş gücü piyasasına katılımın artması}

Bir ülkede sosyal adaletin sağlandığının göstergelerinden birisi de İşgücüne katılım oranı düzeyidir. Bu oranın yüksek olması sosyal refahın daha iyi sağlandığının bir göstergesi olabilir. Nitekim İşe yerleşen bireylerin istihdam edilmeyenlere göre sabit ve sürekli bir geliri olduğundan en azından temel düzeyde intiyaçlarını karşılayabileceği söylenebilir. Türkiye'de bu oranın çok yüksek olmadığı görülmektedir Bununla birlikte son birkaç yıl istisna tutulduğunda işgücüne katılım oranı az da olsa sürekli artmaya devam etmiştir. Bu yüzden bu durum sosyal adaletin sağlanması konusunda olumlu bir gelişme olarak gösterilebilir. 
Aşağıda Tablo 2'de Türkiye'nin 2014-2020 yılları arasında İşgücüne katılım istatistikleri verilmiştir.

Tablo 2.Türkiye 2014-2020 Dönemi İşgücüne Katılma İstatistikleri

\begin{tabular}{|cc|} 
Yıllar & İşgücüne Katılım Oranı (\%) \\
2014 & 50,5 \\
2015 & 51,3 \\
2016 & 52 \\
2017 & 52,8 \\
2018 & 53,2 \\
2019 & 53 \\
2020 & 49,3 \\
\hline
\end{tabular}

Kaynak: Tüik, İsgücü Istatistikleri,2020.

Tablo 2'de de görüleceği üzere Türkiye'de işgücüne katılım oranı 2014-2018 dönemi içerisinde az da olsa sürekli artmıştır. 2018 yılından itibaren işgücüne katılım oranı düşmeye başlamış ve 2020 Covid 19 salgını ile ülkelerde ortaya çıkan küresel ekonomik daralma ile Türkiye'de de diğer ülkelerde olduğu gibi işgücüne katııım oranı hissedilir düzeyde azalma gerçekleşmiştir.

\section{$\checkmark$ Engelli ve bakıma muhtaç kişilere yönelik Sosyal güvenlik ve sosyal yardımların artırıması}

Toplum içerisindeki korumaya ve bakıma muhtaç kişiler ile doğuştan ya da sonradan engelli olan kişilerin hayatlarını idame ettirebilmelerinin sağlanması ve bu kişilerin var olan dezavantajlı durumlarının toplum içerisinde ortaya çıkaracağı sorunların en aza indirilmesini sağlamaya yönelik bir takım düzenlemelerin varlı̆̆ı sosyal açıdan adaletin işlettirildiğinin bir işaretidir.

\section{$\checkmark$ Kaynakların adil ve dengeli dağıtımının sağlanması}

Ekonomide var olan kıt kaynakların kamu kesimi ile özel kesim arasında dengeli bir şekilde dağıtımın sağlanması refahın yeniden dağııımı açısından büyük öneme sahiptir. Piyasa ekonomisinde devletin müdahalesine gerek olmadan kaynakların dengeli dağııııının her zaman sağlandığı söylenemez. Piyasa süreci devlet geleneğine göre daha rekabetçi bir yapı sergilediğinden dolayı kaynakları fertler toplumun geneline değil, daha çok kendi öz çıkarlarına hizmet edecek şekilde kullanma eğilimindedirler. Bu yüzden devletin piyasa süreci içerisinde bozulan kaynak dağılımı dengesini yeniden tesis etmek üzere bir takım araçlar ve yasal düzenlemelerle bunu sağlaması gerekir

\section{$\checkmark$ Adil bir vergi düzeninin varlığı}

Sosyal adaletin sağlanmasında en önemli konuların başında ülkelerin uyguladıkları vergi sistemleri ve ülkelerdeki vergi düzeninin adalet boyutudur. Temel olarak dolaylı vergilerin adaleti sağlamada daha uzak olduğu ve dolaysız vergilerin ise adalete daha uygun olduğu yönünde literatürde bir kanaat mevcuttur. Bu yüzden bir ülkede dolaylı vergi oranı dolaysız vergilere göre daha düşük ise sosyal adaleti sağlama konusunda ülke geride kalmış denilebilir. Türkiye'de maalesef dolaylı vergilerin oranı uzun yıllardan beri dolaysız vergilerden yüksek oranda olmuş ve bu sorunun farkında olunmasına rağmen sorunu çözmeye yönelik ciddi adımlar atılamamıştır. Bunda dolaylı vergilerin mali anesteziye daha uygun olması ve siyasi risk açısından dolaylı vergilerin tercih edilmesinin daha uygun olması etkin olmuştur. Ayrıca vergi sistemi içerisinde negatif vergi denilen en az geçim indirimi uygulamasının uygulama biçimi de sosyal adaleti etkileyen diğer bir vergisel durumdur.

Asgari geçim indirimi ya da en az geçim indirimi ile ifade edilmek istenen bireyin kendisini ve bakmakla yükümlü olduğu ailesini geçindirmeye yetecek kadar olan gelirinin vergi dışı bırakılmasıdır. Bireyleri asgari ihtiyaçları ile kastedilen şey sadece yeme içme gibi fiziksel nitelikte değil ayrıca kültürel nitelikte de bir takım ihtiyaçların karşılanabilmesidir. Örneğin ayda bir tiyatro ya da sinema intiyacı asgari kültürel ihtiyaç sayılabilir. Yine asgari düzeyde eğitimini alabilmesi için bir takım kırtasiye, yol gibi masrafları karşılayabiliyor olması gerekir (Pürsünlerli,2003:14). 
Türkiye'de sayılı Gelir Vergisi Kanunu içinde 35. Maddede yer alan asgari geçim indirimi uygulaması ücret geliri elde edenlere yönelik uygulanmakta ve ifade olarak şu şekilde tanımlanmaktadır:

"Ücretin elde edildiği takvim yılı başında geçerli olan ve sanayi kesiminde çalışan 16 yaşından büyük işçiler için uygulanan asgarî ücretin yıllık brüt tutarının; mükellefin kendisi için \% 50'si, çalışmayan ve herhangi bir geliri olmayan eşi için \% 10'u, çocukların her biri için ayrı ayrı olmak üzere; ilk iki çocuk için \% 7,5, üçüncü çocuk için \%10, diğer çocuklar için \% 5'idir."

Asgari geçim indirimi uygulaması Türk Vergi Sistemi içerisinde yalnızca gerçek usulde vergilendirilen ücretli kişilere yönelik uygulanmaktadır. Bu uygulama ile öncelikle asgari düzeyde ücret geliri elde eden kişilerin kazandıkları net gelirin biraz daha fazla artırılmasının sağlanması hedeflenmiştir. Bununla beraber gelir seviyesi hangi düzeyde olursa olsun eğer ücret geliri elde ediyorsa bu uygulamadan yararlanabilmektedir (Bozdoğan vd., 2012: 130).

Tablo 3'de Türkiye'de 2014-2020 yılları arasını kapsayan ilk ve son altı aylık dönemlerde asgari geçim indirim tutarlarına ait günlük ve aylık miktarlar ve bir önceki yıla göre artış oranı yer almaktadır.

Tablo 3.Türkiye'de Günlük ve Aylık Asgari Ücretler

\begin{tabular}{|c|c|c|c|}
\hline Asgari Ücret & $\begin{array}{c}\text { Asgari Geçim } \\
\text { İndirimi Tutarları } \\
\text { (Günlük) }\end{array}$ & $\begin{array}{c}\text { Brüt Asgari Ücret } \\
\text { Tutarı } \\
\text { (Aylık) }\end{array}$ & $\begin{array}{c}\text { Asgari Geçim } \\
\text { İndiriminin Bir Önceki } \\
\text { Yıla Göre Artış Oranı } \\
\text { (\%) }\end{array}$ \\
\hline 01.01.2014-30.06.2014 & 35,70 & 1071 & 4,8 \\
\hline 01.07.2014-31.12.2014 & 37,80 & 1134 & 5,9 \\
\hline 01.01.2015-30.06.2015 & 40,05 & 1201,50 & 6,0 \\
\hline 01.07.2015-31.12.2015 & 42,45 & 1273,5 & 6,0 \\
\hline 01.01.2016-31.12.2016 & 54,90 & 1647 & 29,3 \\
\hline 01.01.2017-31.12.2017 & 59,25 & 1777,5 & 7,9 \\
\hline 01.01.2018-31.12.2018 & 67,65 & 2029,5 & 14,2 \\
\hline 01.01.2019-31.12.2019 & 85,28 & 2558,40 & 26,1 \\
\hline $01.01 .2020-31.12 .2020$ & 98,10 & 2943 & 15,0 \\
\hline
\end{tabular}

Kaynak: Özdemir,2019: 55.

Tablo 3'e yer alan bilgilere göre asgari ücret miktarında en yüksek artışın sağlandığı sene 2016 yılıdır(\%29,3). Yine tabloya göre asgari ücret miktarında en düşük artış oranı 2014 senesinde gerçekleşmiştir(\%4,8).

Tablo 4'de ise seçilmiş bazı OECD ülkelerinde yer alan çocuk yardımları çocuk sayısına bağlı olarak değişmektedir. Bu yarımlar içerisinde Türkiye'nin ödediği çocuk yardımı tutarları diğer Avrupa ülkeleri ile kıyaslandığında çok düşük seviyelerde kalmaktadır. Bu konuda atılması gereken adımlar olmalıdır. 
Tablo 4. Seçilmiş OECD Ülkelerinin Çocuk Yardımları Tutarlar (2019)

Çocuk Yardımları (Yıllık)

\begin{tabular}{|c|c|c|c|c|}
\hline Ülkeler & 1.Çocuk & 2.Çocuk & 3.Çocuk & $\begin{array}{c}4 \text { ve Sonrası } \\
\text { Çocukları }\end{array}$ \\
\hline Almanya & 2328 Euro & 2328 Euro & 2400 Euro & 2700 Euro \\
\hline Estonya & 660 Euro & 660 Euro & 3600 Euro & 4800 Euro \\
\hline Danimarka & - & - & - & - \\
\hline Hollanda & 1.152 Euro & 2040 Euro & - & - \\
\hline \multirow{2}{*}{ Belçika } & 1.155 Euro & 1120 Euro & 3155 Euro & \multirow{2}{*}{ - } \\
\hline & 1.564 Euro & 2948 Euro & 3983 Euro & \\
\hline Fransa & 1.566 Euro & 1566 Euro & 3572 Euro & 5579 Euro \\
\hline İtalya & 1.140 Euro & - & 2400 Euro & 2400 Euro \\
\hline İspanya & 2.400 Euro & 2700 Euro & 4000 Euro & 4500 Euro \\
\hline Türkiye & 65,66 Euro & 131.31 Euro & 196,95 Euro & 262,61 Euro \\
\hline
\end{tabular}

\section{Kaynak: Özdemir, 2019:80.}

Tablo 4 incelendiğinde en yüksek miktarda verilen çocuk yardımının Fransa, Estonya ve İspanya'da olduğu görülmektedir. Bununla birlikte sırasıyla Belçika, Almanya ve italya ve Hollanda uyguladıkları çocuk yardım miktarlarında yine yüksek miktarlarla dikkati çekmektedir. Burada tüm ülkeler açısında değişmeyen ortak husus, ailelerin çocuk sayısı arttıkça ailelere verilen çocuk yardım miktarların da da artış sağlanmasıdır.

\section{$\checkmark$ Eğitimde Fırsat Eşitliği}

Sosyal adaletin sağlanmasında başta sayılan kriterler önemli olmakla birlikte eğitimde fırsat eşitliğinin sağlanması kriteri sosyal adaleti sağlamada temel faktör olarak devriye girmektedir. Doğuştan gelen ekonomim açıdan bir takım şanssız durumların nesiller arası aktarımının azaltılması ve önüne geçilmesinde eğitimde fırsat eşitliği sunmak hayati öneme sahiptir. Bunun sağlanabilmesi adına kamu tarafında sunulan eğitim hizmetinin olabildiğince yüksek kalitede olması gerekir. Özellikle yüksek öğretimde sunulan eğitimin tatmin edici olması ve istihdam koşullarına yetecek düzeyde bilgi birikimi ile öğrencilerin donatılması ileride yüksek ücretten işe başlama durumlarını etkileyecektir. (Sunal,2011:286).

\subsubsection{Sosyal Adaletin Sağlanmasında Bir Politika Önerisi Olarak Evrensel Temel Gelir}

Evrensel Temel Gelir, her vatandaşın koşulsuz, bürokrasisiz ve vergilendirilemez olarak açıı sınırının üzerinde bir vatandaşık maaşı almasına dayanan bir refah programıdır. Evrensel Temel Gelir aynı zamanda sosyal ve psikolojik zenginlik üzerine kurulmuş gelecekteki bir toplumu garanti edebilir. (Allegri ve Foschi, 2020). Evrensel Temel Gelir, yöntem olarak kamuoyunda iki şekilde tartışıla gelmiştir. Birinci nokta, tüm refah programlarının kaldıııması ve bundan 
doğan bütçe fazlalarının her vatandaşa bir temel gelir olarak kullanılmasıdır. íkinci nokta ise, var olan refah programlarının üzerine eklenecek bir Evrensel Temel Gelir programının yeni vergiler yoluyla finanse etmeye dayanmasıdır (Molina,2020). Bu makalede var olan refah devleti programlarının, etik ve metodolojik olarak yanlışlığına değinildiği için, tartışacağımız nokta tüm refah programlarının kaldırıması ve yerine Evrensel Temel Gelir 'in ikame edilmesi olacaktır.

Devletin asli görevlerinden ilki ve en önemlisi güvenliktir. Güvenlik hizmeti, her ne kadar dış politikada egemenlik alanının ordu yoluyla, iç politikada ise asayişin polis yoluyla güvence altına alınması olarak tanımlansa da, bir vatandaşın hayatını korku duymadan geçirmesi de güvenlik hizmeti kapsamına girmektedir. Korkuların en büyük noktası, ekonomik olarak geleceği görememekten dolayı gerçekleşir. Evrensel Temel Gelir, bir bireyin ekonomik kaygı duymadan, iş hayatını istediği yönde çizmesi açısından bir güvenlik önlemidir.

Evrensel Temel Gelire yöneltilen en büyük ve ayakları en çok yere basan eleştiri ise, insanlara karşılıksız temel bir gelir sağlandığı takdirde insanların tembelleşeceği, hatta üretimden çekileceği şeklindedir. Burada gözden kaçırılan ilk nokta, Evrensel Temel Gelirin bireyleri açlık sınırından çıkaracak şekilde belirlenecek olmasıdır. Yani, Evrensel Temel Gelir ile öncelenen şey; bireylerin en temel intiyaçlarını karşılama sorumluluğu olmaksızın bireylerin üretken faaliyetlere devam etmesidir. Evrensel Temel Gelir, her insanın temel intiyaçlarını karşılayabilmek konusunda endişe duymamasını sağlayacağı için, insanların olağan şartlar altında temel intiyaçlarını karşılayabilmek için harcayacakları zaman ve enerjiyi istedikleri işlerde çalışmak, sevdikleri meslekleri öğrenmek ya da ilgi duydukları çeşitli sanatsal faaliyetlerde kendilerini geliştirmek için kullanmalarına imkân tanıyarak onları daha verimli bireyler haline getirmektir. Ayrıca, evrensel temel gelir deneyleri bize faydalanıcıların tembelleşmediğini aksine enerjilerini kendileri için daha önemli olan alanlara kanalize ettiklerini göstermektedir. 1970'lerde Kanada özelinde yapılan Evrensel Temel Gelir pilot çalışmasının faydalanıcısı olan bireylerin sadece \%1'i çoğunlukla çocuk bakımına ve ailesine daha çok vakit ayırmak amacıyla çalışmayı bırakmış ve haftalık ortalama çalışma süreleri \%10'dan daha az bir biçimde azalmıştır. Bu uygulama, evrensel temel gelir düşüncesinin bütünüyle teorik ve varsayımsal bir yaklaşım olmaktan ziyade onun pratikte de olumlu sonuçlar yaratabileceğinin bir işareti olarak kabul edilebilir (Martinelli, 2020).

Bunun yanı sıra Evrensel Temel Gelir, ekonomik yetersizliklerden dolayı dağılmaya mahkûm olan ailelerin temel geçimini garanti altına alarak normal şartlarda geçimini sağlayamadığı için dağılan ailelerin çocuklarının suça sürüklenmelerini ya da istemedikleri güvencesiz işlerde çalışmalarını engelleyerek ve ailelerin çocuklarına daha ilgili olma imkânı tanıması açısından aile kurumunun sağlıklı bir şekilde işlemesini sağlayacak ve böylece toplumsal düzen ve huzurun korunması konusunda da olumlu bir etki yapacaktır.

Evrensel Temel Gelire yöneltilen ikinci eleştiri ise, bu denli büyük bir refah programının nasıl finanse edileceği yönünde olmaktadır. Evrensel Temel Gelir, bir refahın yeniden dağıtılması projesinden ayrı olarak bireyselliği, bürokrasisizleştirmeyi ve eşitliği önceleyen bir programdır. Bu sebeple, devletin üstlendiği emeklilik, eğitim, sosyal yardım ve sağlık gibi hizmetlerinin büyük çoğunluğunun Evrensel Temel Gelir yoluyla ikame edilip özelleştirilmesi öngörülür. Yani klasik refah devletlerinde devletin rolü işveren ve hizmet sağlayanken, Evrensel Temel Gelir sisteminde devlet sübvanse edici bir görev alır. Kısaca bu denli büyük bir refah programını finanse etmek için yeni bütçe oluşturmak değil, var olan bütçeyi daha adem-i merkezi bir şekilde harcamak öncelenir. Hatta Evrensel Temel Gelir, kapsayıcı bir devletin işlemesini sağlayan büyük bürokrasinin çoğunluğunu gereksiz kılması noktasında, kamu maliyesinin bütçesini rahatlatacak bir uygulamadır. Ayrıca bürokraside istihdam edilen eğitimli sınıfın, özel sektörde istihdam edilmesine yol açarak, kamu bütçesinin de büyümesine olanak sağlayabilir.

Türkiye özelinde, 15 yaş üzeri kadınların sadece \%33'ü istihdamda yer almaktadır (https://www.tisk.org.tr/yayin/1359523609-isveren-dergisi--mart-nisan--2019-.pdf). Yine, her 10 kadından 4'ü ne istihdamda, ne eğitimde, ne de çocuk bakımındadır. Kısacası, teorik olarak bugünün şartlarında bir seçim olsa, farazi olarak ne istihdamda, ne eğitimde, ne de çocuk bakımında olan kadınlar partisi en büyük üçüncü parti olacaktır. Üretimde hiçbir katkısı olmayan bu büyük kitle, her halükarda tüketim yapmak mecburiyetindedir. Bu tüketim ise eşler ve babalar tarafından karşılanmakta ve bu yolla kadınlar negatif özgürlüklerinden (hayır deme hakkı) mahrum kalmaktadır.

Devletin uyguladığı refah programları, bir kadın negatif özgürlüklerinden mahrum kaldığı zaman değil, fiziki bir şiddet gördüğü zaman ortaya çıkmaktadır. Bizim yeniden dağıııcı adalet kavramından anladığımız nokta ise, her bireyin dünyaya geldiği andan itibaren fırsat eşitliğine sahip olarak yarışa başlaması olmalıdır. Evrensel Temel Gelir, çıktıları 
regüle edici bir refah mekanizması olmaktan ziyade, çevresel faktörleri ve şans faktörünü evrensel olarak eşitleyen bir refah programıdır. Evrensel Temel Gelir, insanları içine doğduğu ortamın kafesinden çıkartıp, o insanı bir birey olmaya teşvik eden bir güvenlik hizmetidir. Çünkü insanlar, temel bir gelirin kendilerine sağladığı güvence ile bir başkasına muhtaç olmaksızın kendi hayatını bağımsız bir şekilde idame etme fırsatına sahip olacaktır.

Dolayısıyla, bir yeniden dağıtım mekanizması olarak Evrensel Temel Gelir şunun için hedeflemelidir. OECD 'nin 1981 yılında yayınladığı raporda kamu harcamaları ve bütçe sıkıntıları sebebiyle refah devletinin krizde olduğu iddia edilmiş, birçok araştırmacı refah devletinin krizde olduğunu savunmuş, fakat OECD ülkelerinin sosyal harcamalarında ciddi bir düşüş ise görülmemiştir. OECD ortalamasına göre Gayri safi yurt içi hâsıla içerisinde sosyal harcamaların payı 1980'li yıllarda \%15 düzeyinde iken 2010 yılında yüzde 22'ye düzeyine çıkmıştır. Türkiye'de bu dönem içerisinde sosyal harcamaların gayri safi yurtiçi hasılaya oranı yüzde 3'ten yüzde 12 seviyelerine ulaşmıştır. Son 40 yılda harcama kalemlerinde kamu masraflarını azaltmaya yönelik girişimlerle, toplumsal beklentilerin yönetilmesi için bazı reformlar yapılması neticesinde henüz istenilen seviyelerde oluşmasa da reformların amacı refah devletinin kazanımlarını arttırmak olmuştur (https://ilke. org.tr/bildigimiz-refah-devletinin-sonu-pandemi-ve-sonrasi).

\subsubsection{Türkiye'de Sosyal Adaleti Sağlamada Yasal Zemin ve Diğer Uygulamalar}

Türkiye'de Negatif Vergi Uygulamaları Son yıllarda Türkiye'de kamusal sosyal yardım kapsamında negatif gelir vergisi uygulamalarında artış görülmektedir. Türkiye'de kamu tarafından yapılan sosyal yardımları belirli aralıklarla düzenli olarak verilen Sosyal Yardımlaşma ve Dayanışma Teşvik Fonundan (SYDTF) ayrılan kaynaklar ve Sosyal Yardımlaşma ve Dayanışma Vakıfları (SYDV) tarafından mütevelli heyetlerin kararına göre verilen yardımlar olmak üzere ikiye ayırabiliriz. Bu yardımlar kurallı, düzenli ve belli kriterlere dayalı ve hem alanlarda minnettarlık hissetirme oranı düşük, hem de verenler tarafından da devletin verdiği bir hak olarak görülmesi itibariyle, daha hak temelli yardımlardır. Verme bakımından zekât uygulamaları ile örtüştüğü söylemek mümkündür. Diğer yardımlar düzenli olmaması, kimlere hangi durumlarda verileceğinin belirsiz olması itibariyle hem mütevelli heyetlerin keyfiyetine ve farklı uygulamalarına tabi olmaları, hem de alanlarda bir tür lütuf hissiyle, minnettarlık oluşturma ihtimali olan yardımlardır. Türkiye genelinde kamu ve STK lara bağı vakıflar da olduğu gibi Sosyal Yardımlaşma ve Dayanışma Vakfının(SYDV) gelirleri, arasında fitre ve zekat ta yer almaktadır (Dodurka,2014, 15).

Buna göre Türkiye'de uygulanan negatif gelir vergisi kapsamındaki sosyal yardımları bazı örnekler şunlardır (https://www.ailevecalisma.gov.tr/sygm/programlarimiz/sosyal-yardim programlarimiz/) ;

a)Eşi Vefat Etmiş Kadınlara Yönelik Düzenli Nakdi Yardım Programı: Kadınların yoksulluktan daha çok etkilendiği rasyonalitesinden hareket edilerek meydana getirilen "Eşi Vefat Etmiş Kadınlar" için nakdi sosyal yardım programı getirilmiştir. Sosyal politika düşüncesi çerçevesinde, ilgili vakfın mütevelli heyeti tarafından yardım programından yararlanmasına yönelik karar verilen eşi vefat etmiş kadınlara muhtaçlıkları ve koşulları sağlama vaziyetleri devam ettiği süre içerisinde aylık 325 TL olmak üzere 2 aylık periyotlarla 700 TL aksatılmadan nakdi yardım verilmektedir.

b)Barınma Yardımları: Oturulamayacak derecede eskimiş, düzensiz ve sağlık açısından risk barındıran evlerde yaşayan ihtiyaç sahibi kişilere evlerinin bakım ve tamiri için ayni veya nakdi olarak yapılan yardımlardır. Bu yardım programı ile evlerinin bakımını yapamayacak durumda olan ve zor şartlarda hayatını idame ettirmeye çalışan vatandaşlarımız sağlıklı ve sıcak bir yaşam ortamına kavuşmaktadır. Bu uygulamaya ek olarak ihtiyaca göre ve yardım için belirlenmiş şartlara uymak koşuluyla ev tamirlerinde 20.000.-TL, prefabrik ev inşalarında 30.000.-TL, betonarme ev inşalarında 40.000 TL'ye kadar destek verilir.

c) Eğitim Yardımları: Yoksul bireylerin eğitim olanaklarına ulaşabilirliğinin düşük olması eğitimde fırsat eşitliğini zorlaştırmakta ve yoksulluğun nesilden nesle aktarılmasının ortadan kaldırılmasında çok büyük problemi teşkil etmektedir. Etkili bir sosyal yardım politikası meydana getirilmesinde ve yoksullukla mücadelede başarılı olunmasında eğitim faktörü çok kritik bir önem taşımaktadır. Aile ve Sosyal Politikalar Bakanlığı bu realiteden hareketle fon kaynağının büyük bir kısmını eğitim yardımları için harcamaktadır.

d)Şartı Eğitim Yardımı: Nüfusun en yoksul \% 6’ıı kesiminde yer alan ve maddi olanaksızlıklar sebebiyle çocuklarını okula gönderemeyen ailelere, çocuklarının okula devam etmeleri koşuluyla, "Şartlı Eğitim Yardımı" yapılmaktadır. Kız çocuklarına sağlanan yardım tutarı erkek çocuklarına yapılan yardım tutarından daha yüksektir. Aylık ödeme tutarları: illköğretime devam eden erkek öğrenci için/aylık 45 TL -illköğretime devam eden kız öğrenci için/aylık 50 TL - 
Ortaöğretime devam eden erkek öğrenci için/aylık 55TL -Ortaöğretime devam eden kız öğrenci için/ aylık 75 TL olarak tespit edilmiştir.

e)2022 Sayılı Kanun kapsamındaki İş ve İşlemler: 2022 No'lu “65 Yaşını Doldurmuş Muhtaç, Gücü yerinde olmayan ve Kimsesi olmayan Türk Vatandaşlarına Aylık Bağlanması Hakkında Kanun" kapsamında 65 yaş üstündekilere ve engelli vatandaşlara SGK kaydı olmamak ve aylık geliri asgari gelirin 1/3'ünden az olması koşuluyla sağlanan parasal ve düzenli ödenen aylıklardır. 2014 yılı için yaşılır için aylık 446,57 TL, \%40-69 arasındaki engelliler için 893,17 TL ve \%70 üstü engelliler için 1339,74 TL'dir. Bu nakit ödemelerde asgari gelir desteği özelliğindedir.

f)Muhtaç Asker Ailesi Yardımı: Askere gitmiş/gidecek olan kişinin, kanunla kurulu sosyal güvenlik kuruluşlarına tabi olmayan ve askerlik dolayısıyla belirli dönemler itibariyle yoksulluk riski barındıran, fakir ve intiyaç sahibi durumda olduğu Mütevelli Heyet kararıyla onaylanan resmi nikahlı eşi veya anne-babası bu destekten faydalandırılır. Ödemeler iki ayda bir 250,00TL. olmak üzere toplam 500,00TL. PTT vasıtasıyla hak sahibi kişilere ödenir(KHK, 2011 :5)

g)Konut hesabı ve Devlet katkısı: Sosyal güvenceye sahip olmayan, muhtaç kişilere Toplu Konut idaresi vasıtasıyla ev yapımını kapsamaktadır. Bu bağlamda geri ödemeli olarak sosyal konut sağlanır. Geri ödemeler 1+1 konutlar için ayda 100 TL; 2+1 konutlar için 130 TL olmak üzere 270 ayda tamamlanmaktadır.

h)Doğum yardımı: Türk vatandaşlarına, canlı doğan birinci çocuğu için $300 \mathrm{TL}$, ikinci çocuğu için $400 \mathrm{TL}$, üçüncü ve sonraki çocukları için 600 TL doğum yardımı yapııı. Bu yardım Türk vatandaşı olan anne veya babaya, her ikisi de Türk vatandaşı ise anneye yapılır. (KHK, 2011, 5)

j)Kadın İstihdamının Desteklenmesi İçin Büyükanne Projesi: Kadın İstihdamının Desteklenmesi İçin Büyükanne Projesi'nin amacı, 3 yaşını doldurmayan torununa bakan büyükannelere verilecek yardım ile hâlihazırda çalışıyor olan kadınların işgücü piyasasından çekilmelerini önlenmek ve çocuklara büyükanneleri ile birlikte büyüme imkânı sağlayarak kültür aktarımına destek olmaktır. Büyükanne Projesi kapsamında, annenin fiilen çalışıyor olması kaydıyla, 3 yaşını doldurmayan torununa bakan büyükannelere 12 ay süreyle $425 \mathrm{TL}$ karşılıksız maddi destek verilecektir (www.ailevecalisma.gov.tr, 2021).

Sonuç olarak Türkiye'de negatif vergi uygulamaları yukarıda da bahsedildiği gibi, Eşi Vefat Etmiş Kadınlara Yönelik Düzenli Nakdi Yardım Programı, Barınma Yardımları, Eğitim Yardımı, Şartı Eğitim Yardımı, Asgari Geçim İndirimi,2022 Sayııı Kanun kapsamındaki İş ve İşlemler, Muhtaç Asker Ailesi Yardımı, Çeyiz hesabı ve Devlet katkısı, Konut hesabı ve Devlet katkısı, Doğum yardımı, Kadın İstihdamının Desteklenmesi İçin Büyükanne Projesi alanlarında uygulanmaktadır.

Tablo 5'de Türkiye'de sosyal adaleti sağlamaya yönelik Uygulamaların evrensel temel gelir açısından uygunluğu değerlendirilmeye çalışımıştır. Bu anlamda Türkiye'nin yoksulluğun azaltılması, İsgücüne katılım oranları, Engelli ve bakıma muhtaç kişilere yapılan yardımlar, adil vergi düzenin sağlanması ve özellikle eğitimde fırsat eşitliğinin sağlanması gibi hususlarda eksiklikleri bulunmaktadır. Bu konularda geliştirilmeye intiyaç vardır. Hükümetin bu konudaki çabalarını artırması gerekmektedir.

Tablo 5. Türkiye'de Refahın Yeniden Sağlanmasına Yönelik Uygulamaların Evrensel Temel Geliri Sağlama Açısından Kıyaslanması

\section{Uygulama Türü}

\section{Evrensel Temel Gelir Açısından Uygunluk}

\section{Sosyal Adaleti Sağlamaya Yönelik Kriterler Açısından Yer Alan Uygulamalar}

Yoksulluğun Azaltılması

İsgücüne Katılımın Artırılması

Engelli ve bakıma muhtaç kişilere yönelik Sosyal güvenlik ve sosyal yardımların artırıması
Geliştirilmeye ihtiyaç var.

Geliştirilmeye intiyaç var.

Doğrudan nakit yardımı sadece belirli engellilere yönelik, bir takım zor koşulları sağlamaları halinde var.

Engelli aylığı daha tatminkar bir seviyeye çıkarılmalıdır.

Geliştirilmeye ihtiyaç var. 
Adil Bir Vergi Düzeninin Varlığı

\section{Uygulama Türü}

Vergi sisteminde dolaylı vergilerin yoğunluğu zorunlu malları alan dar gelirli bireyler üzerinde vergi yükünü artırmaktadır. Geliştirilmeye ihtiyaç var.

En az geçim Indirim tutarları artırılmalı

Çocuk yardımları yükseltilmeli

\section{Evrensel Temel Gelir Açısından Uygunluk}

\section{Aile ve Sosyal Politikalar Bakanlığı Tarafından Sunulan Yardımlar}

Eşi Vefat Etmiş Kadınlara Yönelik Düzenli Nakdi Uygundur.

Yardım Programı

Barınma Yardımları

Uygun

Eğitim Yardımları

Bu kriterin diğer kriterlere göre öncelikle geliştirilmeye ihtiyacı var.

Şartlı Eğitim Yardımı

Asgari Geçim İndirimi Uygulaması

2022 Sayılı Kanun kapsamındaki İş ve İşlemler

Muhtaç Asker Ailesi Yardımı

Konut hesabı ve Devlet katkısı

Doğum yardımı

Kadın İstihdamının Desteklenmesi İçin Büyükanne Projesi

\section{Uygun}

Geliştirilmeye intiyaç var

Uygun

Uygun

Uygun

Uygun

Doğru bir uygulama devam edilmeli

Kaynak: Bu tablo konunun daha iyi anlaşılabilmesi amacıyla yazar tarafından oluşturulmuştur.

\section{Sonuç}

Günümüzün sosyal güvenlik uygulamalarını da içselleştirecek şekilde kapsayıcı olan modern refah devletinin temelleri, kendisine ikinci dünya savaşı sonrası yoksulluğu azaltacak ve ekonomiyi canlandıracak bir formül bulma görevi verilen İngiliz William Beveridge ile ortaya atılmıştır. (Sloman, 2018). Görüyoruz ki günümüzde derin bir ekonomik krize neden olan koronavirüs (covid-19) salgını sonrası dünya ekonomisi 'evrensel temel gelir-herkese temel gelir ' uygulamaları daha fazla tartışır hale gelmiştir.

İçinde bulunduğumuz 2020 yılı, makroekonomik dengeleri değiştirmiş, öngörülebilirliği azaltmış ve insan sağlığının her şeyin üstünde olduğu göstermiştir. Bu nedenle hükümetlerin refah devleti idealinden uzaklaşmaması gerekmektedir. Çünkü Dışsallıkların, borçlanma kısıtlamalarının ve parasal genişlemenin olduğu bir küresel ekonomik sistem içinde COVID-19 gibi büyük bir olumsuz şokla beraber, insanlar hastalığın yayılmasını sınırlamak için önlemlere uymak zorunda ve bu durum ekonomik faaliyetleri azalttıkça da GSYiH düşmektedir. (Loayza ve Pennings, 2020). Ancak gerçek dünyada, COVID-19'un uzun süreli ve derin bir durgunluk ve keskin ekonomik dalgalanma yaratması muhtemeldir (Furman 2020). Makroekonomik politikaların amacı da, bu dalgalanmaların kısa ömürlü olmasını ve refah devletinin varlığını hissettirmesi için bir bakıma durgunluğu, talep dışsallıklarını hafifletmeli ve olumsuz şokların etkisini en aza indirgeyerek bu yönetim sürecinde birlikte hareket ettiği parasal ${ }^{a}$ ve mali araçları ${ }^{b}$ kullanmalıdır. (Bernanke 2020; Blinder ve Zandi 2015; Galí ve Gambetti 2009)

\footnotetext{
aparasal araçlar, kısa vadeli piyasa oranlarını etkilemek için bir politika faiz oranı belirlemeyi, uzun vadeli piyasa oranlarını yönlendirmek için varlık alımlarını takip etmeyi, likidite sağlamayı ve son çare olarak borç vermeyi içerir. Faiz oranı indirimleri, öncelikle tüketimi ve yatırımı teşvik ederek toplam talebi artırmaya yardımcı olur ve tüm parasal araçlar, finansal sürtüşmelerin olumsuz etkisini azaltmaya yardımcı olur.

b Mali araçlar arasında hükümet tüketimi ve sermaye harcamaları; emek geliri, kar, mal ve hizmet vergileri ve sübvansiyonların, transferlerin ve vergi muafiyetlerinin sektörel dağılımları. Gelir desteği sağlayarak firmaların ve tüketicilerin borçlanma ihtiyacını azaltabilirler. Ayrıca talep şoklarına
} 
Evrensel Temel Gelir uygulaması (ETGU), standart sosyal devlet uygulamalarından kaynaklanan ahlaki çıkmazı ve metodolojik aksaklıkları çözme iddiasında olan bir refah devleti programıdır. Evrensel Temel Gelir uygulamasının klasik refah devleti programlarından ayrıldığı noktanın, klasik refah programlarının gelir eşitliğini önceleyen, mağduriyet giderici, yoksulluk ve işsizlik gibi temel sorunların önüne önüne geçme potansiyelinden dolayı önemli nitelikte olduğu bilinmektedir. Oysaki Evrensel Temel Gelir, fırsat eşitliğini önceleyen, mağduriyet önleyici nitelikte bir program olmasından dolayı ister koronavirüs gibi küresel bir kriz ister günlük ekonomik yaşamın konjonktürel dalgalanmaları olsun ekonomik güvenliği sağlamada sürdürülebilir güçlü bir kaldıraç görevi üstlenebilecektir.

Ayrıca, ETGU'nun refahın yeniden dağııımı gibi çetrefilli bir konuyu devletin merkezi planlama birimlerinden alarak, doğrudan bireysel tercihlere bırakması noktasında önemlidir. Yani Evrensel Temel Gelir uygulaması bir politika yapım süreci yaratmaz, aksine başlı başına bir kurum olarak hükümetlerden bağımsız bir biçimde faaliyet gösterir. Fakat birçok ülkede farklı yöntemlerle birlikte uygulanan ve bir çeşit vatandaşlık hakkı gibi yorumlanan, toplum her bir ferdini çalışma isteğinden vazgeçirmeden, en temel insanî gereksinimleri sunan ETGU, Portekiz, Finlandiya, ABD, Brezilya, Almanya, İran ve Fransa'da uygulanmaktadır. Türkiye'de ise Asgari Geçim İndirimi uygulaması bulunmakta olup ETGU ile birebir örtüşmemektedir. Yani Türkiye'de Evrensel Temel Gelire bir intiyaç duyulduğu küresel sağlık kriziyle belirgin bir şekilde ortaya çıkmıştır.

Bu noktada ETGU, bireylerin tercihini öncelemekle eşzamanlı olarak bir standart getirmesinin yanında, klasik refah devleti programlarından daha verimli bir biçimde çalışabilir. Ekonomik kalkınma ancak sosyoekonomik ve teknolojik faktörlerin işgücü üzerinde eşitsizliği arttıracak faktörlerin, toplumsal huzursuzlukla ortaya çıkacak derin psikolojik sorunların ve hane halkına etki edecek ekonomik sıkıntıların önüne geçilmesiyle mümkün olabilir. Bu nedenle regülasyon otoritelerince planlamaların yapılması ve senaryo analizleriyle mali açıdan olası sonuçlarının test edilmesi, bunun neticesinde de toplumsal refaha katkı sağlanması yararlı olacaktır.

Sosyal adaletin sağlanmasında yer alan bazı kriterler bulunmaktadır. Bunları, Yoksulluğun azaltılması, İşgücüne katıım oranın artırıması, adil bir vergi düzenin sağlaması, eğitimde fırsat eşitliği oluşturulması ve engelli ve bakıma muhtaç bireylerin desteklenmesi şeklinde sıralamak mümkündür. Türkiye açısından durum değerlendirilmesi metin içerisinde yapılmış ve evrensel gelir açısından da bu kriterlerin uygunluğu özet tabloda sunulmuştur. Varılan neticede özellikle yoksulluğun azaltılması, eğitimde fırsat eşitliği ve işgücüne katılım oranı ve adil düzenin varlığı konularında evrensel gelire ulaşılama konusunda yeterli adımların atılamadığı görülmektedir. En az geçim indirimi uygulaması ki bireylerin temel düzeyde ihtiyaçlarını karşılayabilecekleri ve hayatlarını idame ettirebilecekleri geliri sağlama konusunda bile yetersizlikler vardır. Bu konuda geçmiş dönemlere kıyasla özellikle son 15 yıl içinde iyileşmeler yaşansa da asgari ücretin iyileştirilmesi konusu da hala adım atılması gereken konular arasında tazeliğini korumaktadır

Türkiye'de sosyal adaletin sağlanması ve dolayısıyla refahın bireyler arasında yeniden dağııılmasında bir takım uygulamaların olduğu söylenebilir. Bunlar arasında, Eşi Vefat Etmiş Kadınlara Yönelik Düzenli Nakdi Yardım Programı, Barınma Yardımları, Eğitim Yardımı, Şartı Eğitim Yardımı, Asgari Geçim İndirimi,2022 Sayılı Kanun kapsamındaki İş ve Işlemler, Muhtaç Asker Ailesi Yardımı, Çeyiz hesabı ve Devlet katkısı, Konut hesabı ve Devlet katkısı, Doğum yardımı, Kadın İstihdamının Desteklenmesi İçin Büyükanne Projesi sayılabilir. Bu tarz yardım programlarının uygulamada iyi niyetli olarak ilgili Bakanlık tarafından ihtiyaç sahiplerine sunulmaya çalışıdığı görülmektedir. Fakat yapılan yardımların büyük bir kısmı evrensel geliri sağlama açısından yeterli görülmemekte; geliştirilmeye ve katkılarının artııılmasına ihtiyaç duyulmaktadır. Çünkü Devletler, sürdürülebilir ekonomik büyümeye kavuşması için öncelikle toplumsal refahı ve sosyal adaleti sağlamalıdır. Sermaye, demokrasi ve refahın arttığı ülkelerde kendini güvenli ve iştahlı hisseder; üretime, istihdama ve gelire dönüşür. Piyasa ekonomisinde üretim araçlarının önemli bir kısmı özel sektörün kontrolünde olduğu için, dışlama etkisi oluşturmadan kaynakların tahsisini, bölüşümünü ve istikrarını etkinlikle sağlamak zorundadır. Bu nedenle ekonomik büyüme ve gelişmenin desteklenmesi istenilirken karar alıcıların sadece günün koşullarını dikkate almamalıdır. Orta ve uzun vadeli rasyonel politika kararları ile toplumsal refahı artıımalı ve ülkelerin ekonomik birikimini gelecek nesillere aktarmalıdır.

karşı koyabilirler: doğrudan, hükümet tüketimini ve yatırımını artırarak ve dolaylı olarak, insanları ve firmaları tüketmeye ve yatırım yapmaya teşvik ederek (vergiler ve transferler yoluyla). 


\section{Kaynakça}

Albayrak, Ö. (2003), Refah iktisadının Teorik Temelleri: Piyasa Refah ilişkisi, Ankara Üniversitesi Sosyal Bilimler Enstitüsü, Yayınlanmamış Master Tezi.

Allegri, G.,\& Foschi, R. (2020). Universal Basic Income as a Promoter of Real Freedom in a Digital Future. World Futures, 1-22.

Arslan, A.(2020).Yatırımcılara Yönelik Harcama Vergisi muafiyet ve İstisna Uygulamalarının Ödeme gücü ve sosyal adalet açısından Değerlendirilmesi, Türkiye'de Yapısal Dönüşüm Mali ve Sosyal Değerlendirmeler(ed) içinde, Ankara: Gazi Kitabevi.

Bernanke, B. S. 2020. "The New Tools of Monetary Policy." American Economic Association Presidential Address, January 4.

Blinder, A., \& M. Zandi. 2015. "The Financial Crisis: Lessons for the Next One." Policy Futures Paper, Center on Budget and Policy Priorities, Washington, DC

Bozdoğan, K., Buyrukoğlu, S., \& Bozdoğan, D. (2012). Sosyal Vergileme İlkeleri Açısından Asgari Geçim Indiriminin Değerlendirilmesi. Vergi Dünyası Dergisi, 375, 128-136.

Briggs, Asa. "The Welfare State in Historical Perspective." In The Welfare State Reader, edited by Christopher Pierson and Francis G. Castles, 18-31. London: Polity Press, 2000.

Çalışkan, ş. (2010). Türkiye'de gelir eşitsizliği ve yoksulluk. Sosyal Siyaset Konferansları Dergisi, (59), 89-132.

Çoban, R. (2017). Sosyal Adalet, Eşitlik ve Sosyal Hizmet. Gümüşhane Üniversitesi Sağlık Bilimleri Dergisi, 6(4), 252-260.

Furman, J. 2020. "Protecting People Now, Helping the Economy Rebound Later." In Mitigating the COVID Economic Crisis: Act Fast and Do Whatever It Takes, edited by R. Baldwin and B. Weder di Mauro, 191-96. Center for Economic Policy and Research. Washington, DC: CEPR Press.

Gafar, John, (1998). "Growth, Inequality and Poverty in Selected Caribbean and Latin American Countries, with Emphasis on Guyana", Journal of Latin American Studies, 30, s.591-617.

Galí, J., \& L. Gambetti. 2009. "On the Sources of the Great Moderation” American Economic Journal: Macroeconomics 1 (1): $26-57$

Karimi, S. (2017). Beyond the Welfare State: Postwar Social Settlement and Public Pension Policy in Canada and Australia. University of Toronto Press, Scholarly Publishing Division.

Loayza, N. V., \& Pennings, S. (2020). Macroeconomic policy in the time of COVID-19: A primer for developing countries.

Martinelli, L. (2020). A Basic Income Trilemma: affordability, adequacy, and the advantages of radically simplified welfare. Journal of Social Policy, 49(3), 461-482.

Molina, G. G., Ortiz-Juarez, E., \& NETWORK, U. G. P. (2020). Temporary basic income: protecting poor and vulnerable people in developing countries. United Nations Dev. Program.

Nadaroğlu, H. (1998)Mahalli İdareler - Teori -Ekonomi - Uygulama, İstanbul: Beta Basım Dağııım.

Nicola, M., Alsafi, Z., Sohrabi, C., Kerwan, A., Al-Jabir, A., losifidis, C., \& Agha, R. (2020). The socio-economic implications

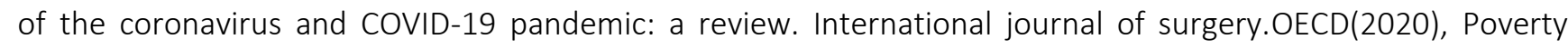
rate(indicator).

Öğretir, A.H.(2020). Maliye Konu Anlatımı, 8. Baskı, Ankara: 4T Yayınevi.

Özdemir, i. B. (2019). En az geçim indiriminin Türk vergi sistemi içerisindeki yeri ve bazı ülke uygulamaları açısından karşılaştırılması (Master's thesis, Balıkesir Üniversitesi Sosyal Bilimler Enstitüsü).

Paine, T (1995) Collected Writings, New York City: Library of America.

Pürsünlerli, E.S.(2003). Ayırma İlkesi Açısından Ücretlerin Vergilendirilmesinde Asgari Ücretin Vergi Dışı Bırakılmasının Etkileri Ve Analizi,Gazi Üniversitesi Sosyal Bilimler Enstitüsü Maliye Anabilim Dalı Doktora Tezi Ankara. 
Rawls, J. (1971) A Theory of Justice, Massachusetts: Belknap Press.

Reeskens, T. (2020). Migration and the welfare state: welfare magnets and welfare chauvinism. In Handbook on Society and Social Policy. Edward Elgar Publishing.

Saha, A. K., \& Mishra, V. (2020). Genetic distance, economic growth and top income shares: Evidence from OECD countries. Economic Modelling, 92, 37-47.

Sen, A, (1973), On Economic Inequality, Clarendon Press, Oxford.

Sloman, P. (2018). Universal Basic Income in British Politics, 1918-2018: From a'Vagabond's Wage'to a Global Debate.

Sönmez, S. (1987), Kamu Ekonomisi Teorisi, Teori Yayınları, Ankara.

Sunal, O. (2011). "Sosyal Politika: Sosyal Adalet Açisindan Kuramsal Bir Değerlendirme". Ankara Üniversitesi SBF Dergisi, 66(03), 283-305.

Todaro, M. P., (2000). Economic Development, Seventh Edition, Addison Wesley, Massachusetts.

Yıldırım, Ö. A. M. (2011). Dünyada ve Türkiye'de yoksulluğun analizi. Niğde Üniversitesi İktisadi ve İdari Bilimler Fakültesi Dergisi, 4(2), 60-76.

https://www.ailevecalisma.gov.tr/sygm/programlarimiz/sosyal-yardim-programlarimiz/ (E.T.24.03.2021).

193 Sayılı Gelir Vergisi Kanunu, 35. Madde. 